\title{
Haematology of Mugil curema from the north coast estuary of Santa Catarina state, Brazil*
}

\section{Hematologia de Mugil curema em estuário no litoral norte do estado de Santa Catarina, Brasil}

\author{
Juliano Santos Gueretz, ${ }^{* *}$ Maurício Laterça Martins, ${ }^{* * *}$ Antonio Pareira de Souza***
}

\begin{abstract}
Resumo
Mugil curema é um peixe teleósteo, abundante em regiões costeiras, estuarinas e lagunares, em todo o litoral brasileiro. Os parâmetros sanguíneos podem ser usados como indicadores da saúde e do bem-estar dos peixes, bem como do ambiente onde estes vivem. O objetivo deste estudo foi verificar o perfil hematológico de $M$. curema ao longo de 18 meses, em águas estuarinas, no Litoral norte do estado de Santa Catarina, sul do Brasil. Um total de 133 peixes foram capturados, entre março de 2016 e agosto de 2017, para realização de eritrograma, leucograma, trombocitograma, porcentagem de hematócrito, dosagem de hemoglobina, dosagem de proteína plasmática total, volume corpuscular médio (VCM), hemoglobina corpuscular média (HCM) e concentração de hemoglobina corpuscular média $(\mathrm{CHCM})$. Não houve diferença significativa $(P>0,05)$ entre o número total de eritrócitos entre machos e fêmeas. No entanto, houve diferença no hematócrito, entre machos e peixes de sexo indeterminado. As influências do espaço temporal e geográfico, entre os valores dos parâmetros hematológicos, nos diferentes estudos do litoral brasileiro são discutidas. A presente investigação é importante contribuição para o estabelecimento de um padrão hematológico para M. curema. A população local de peixes estudada tem comportamento próprio em descritores hematológicos, diferenciado de outros estudos no litoral brasileiro para a mesma espécie.
\end{abstract}

Palavras-chave: Araquari, mugilídeos, parati, rio Parati, tainha.

\begin{abstract}
Mugil curema is a teleost fish often found in coastal, estuarine and lagoon regions throughout the Brazilian coast. Blood parameters may be used as health and welfare indicators of the fish, as well as the environment they live in. The aim of this study was to verify the hematologic profile of the M. curema along 18 months in estuary waters from the north coast of the state of Santa Catarina in the south of Brazil. A total of 133 M. curema fish were captured from March 2016 to August 2017. Erythrogram, leukogram, thrombocytogram, hematocrit percentage, hemoglobin dosage, total plasma protein dosage, mean corpuscular volume (MCV), mean corpuscular hemoglobin $(\mathrm{MCH})$ and medium corpuscular hemoglobin concentration $(\mathrm{MCHC})$ were analyzed. There was no significant difference $(P>0.05)$ on the total number of erythrocytes between the fish gender. However, there was difference on the hematocrit between males and indefinite gender fish. The influences of temporal and geographical space, among the values of hematological parameters, in the different studies of the Brazilian coast are discussed.. The present research is an important contribution to establish a hematological pattern for M. curema. The local population of the studied fish has a proper behavior in hematological descriptors, which is different from other Brazilian coast studies with the same fish species.
\end{abstract}

Keywords: Araquari, mugilids, white mullet, parati river, mullet fish.

\section{Introduction}

Mugil curema Valenciennes, 1836 is a teleost fish popularly known as "tainha" and "tainha-sajuba" in the north and northeast and as "parati" in the southeast and south of Brazil. Mugilid fish are abundant in coastal, estuarine and lagoon regions, even for its dietary characteristics, which is scavenger. It is a catadromous fish that adapts to the variations of water salinity, it survives in both sea and fresh water environment. It is more abundant from October to April, a time period that, partly, coincides to its spawning which is from August to January (Albieri et al. 2010, Fonsêca et al., 2000, Menezes, 1983, Menezes et al., 2015).

The hematology and possible alterations in benchmark hematological patterns, as well as the morphological disorder in blood cells may be used to help monitoring fish and environment health. The blood parameters may be used as biological indicators in monitoring the fish welfare, using it as a tool for diagnosing the animal stress due to the environmental imbalance or due to the presence of infectious agents (Silva et al., 2012). Hematological

\footnotetext{
${ }^{*}$ Recebido em 8 de setembro de 2019 e aceito em 15 de setembro de 2020.

**Instituto Federal Catarinense - IFC, Campus Araquari, Araquari, SC, Brasil.

***Laboratório AQUOS - Sanidade de Organismos Aquáticos - Universidade Federal de Santa Catarina -UFSC, Florianópolis, SC, Brasil.

****Programa de Pós-Graduação em Ciência Animal - Universidade do Estado de Santa Catarina - UDESC, Lages, SC, Brasil.
} 
characteristics in fish vary according to the species, age, gender, diet and environment which they are exposed. Therefore, they are important characteristics to be analyzed when those animals are exposed to stress (Ghiraldelli et al., 2006).

The aim of this study was to verify the hematological profile of the $M$. curema along 18 months in estuary waters from the north coast of the state of Santa Catarina in the south of Brazil.

\section{Material and methods}

The studied site was Parati river located in the city of Araquari, Santa Catarina state, Brazil, within the geographic coordinates $26^{\circ} 23^{\prime} 07.0^{\prime \prime} \mathrm{S} 48^{\circ} 45^{\prime} 07.0^{\prime \prime} \mathrm{W}$ and $26^{\circ} 21^{\prime} 31.8^{\prime \prime} \mathrm{S} 48^{\circ} 42^{\prime} 51.7^{\prime \prime} \mathrm{W}$. 133. From March 2016 to August 2017, the fish were captured by gillnet with a five to seven centimeters net between knots, two meters in height and $150 \mathrm{~m}$ in length, thrown from a power-driven boat, which both the boat and the pilot were properly registered and qualified by the "Capitania dos Portos", Brazil navy, from São Francisco do Sul, SC. After captured, the fish were transported in a plastic container with water of the river, constantly aerated by a portable aerator powered by a $1.5 \mathrm{~W}$ battery.

Blood samples were collected by puncturing the caudal vessel with $3 \mathrm{~mL}$ disposable syringes and $0.7 \times 25 \mathrm{~mm}$ hypodermic needles, previously soaked in a Ethylenediamine Tetra acetic Acid (EDTA 10\%) as anticoagulating. After puncture $2 \mathrm{~mL}$ of blood were placed in a $10 \mathrm{~mL}$ test tube and sent to the hematological laboratory for hematological analyses. corpuscular hemoglobin $(\mathrm{MCH})$ was espressed in pg and the mean corpuscular hemoglobin concentration (MCHC) expressed in $\mathrm{g} \mathrm{dL}^{-1}$ (Ranzani-Paiva et al., 2013).

For statistical analyses, the data were submitted initially to the Shapiro-Wilk test in order to verify the distribution type, its standardization or not. The considered normal data, in its distribution, were submit to variance analysis, and in case it showed difference the Tukey test was applied to check which set, or sets were different. In case of the Shapiro-Wilk test resulted in non-standard data, the set was submitted to standardization using the logarithmic transformation or box-cox type. For the considered non-standard sets, even after the transformation, the KruskelWallis and Mann-Whitney test were applied. In order to assist those analyse the statistical softwares Past and $\mathrm{R}$ were utilized (Andrade e Ogliari, 2013, Hammer et al, 2001, Petrie e Watson, 2009, R Core Team, 2017). The scientific investigation project that led to this study was approved by the Comissão de Ética no Uso de Animais (CEUA) of the Instituto Federal Catarinense - Campus Araquari, certificate $0107 / 2015$ and by the Instituto Chico Mendes de Conservação e Biodiversidade - ICMBio, authorization for scientific purpose activities - SISBIO 48661.

\section{Results}

The hematological parameters of the $M$. curema captured in Parati river from April 2016 to July 2017 are shown in Table 1.

Table 1: Hematology, average and standard deviation of Mugil curema captured in Parati river, Araquari SC, from Mach 2016 to August 2017

\begin{tabular}{lcccc}
\hline & Female & Male & Indeterminate gender & Total \\
\hline Erythrocytes $\left(\times 10^{6} \mathrm{~mL}^{-1}\right)$ & $3.53 \pm 1.05^{\mathrm{a}}(32)^{(1)}$ & $3.96 \pm 1.57^{\mathrm{a}}(26)$ & $3.36 \pm 1.39^{\mathrm{a}}(67)$ & $3.53 \pm 1.36(125)$ \\
$\mathrm{HTC}(\%)$ & $43.63 \pm 5.48^{\mathrm{a}}(32)$ & $39.85 \pm 5.72^{\mathrm{b}}(26)$ & $39.56 \pm 6.88^{\mathrm{b}}(73)$ & $40.61 \pm 6.53(131)$ \\
Hemoglobin $\left(\mathrm{g} \mathrm{dL}^{-1}\right)$ & $15.58 \pm 2.04^{\mathrm{a}}(25)$ & $14.30 \pm 1.78^{\mathrm{b}}(24)$ & $14.77 \pm 2.04^{\mathrm{ab}}(53)$ & $14.86 \pm 2.01(102)$ \\
$\mathrm{MCV}(\mathrm{fL})$ & $135.65 \pm 47.02^{\mathrm{a}}(32)$ & $118.15 \pm 59.23^{\mathrm{a}}(26)$ & $141.72 \pm 74.43^{\mathrm{a}}(67)$ & $135.27 \pm 65.52(125)$ \\
$\mathrm{MCH}(\mathrm{pg})$ & $44.08 \pm 13.28^{\mathrm{a}}(25)$ & $38.63 \pm 17.29^{\mathrm{a}}(24)$ & $43.56 \pm 19.62^{\mathrm{a}}(51)$ & $42.51 \pm 17.65(100)$ \\
$\mathrm{MCHC}(\%)$ & $36.10 \pm 4.88^{\mathrm{a}}(25)$ & $35.85 \pm 1.93^{\mathrm{a}}(24)$ & $36.37 \pm 1.93^{\mathrm{a}}(53)$ & $36.18 \pm 2.91(102)$ \\
TPP $\left.(\mathrm{g} \mathrm{dL})^{-1}\right)$ & $6.43 \pm 0.74^{\mathrm{a}}(32)$ & $5.84 \pm 0.78^{\mathrm{b}}(26)$ & $5.88 \pm 0.91^{\mathrm{b}}(72)$ & $6.01 \pm 0.88(130)$ \\
Leukocytes $\left(\times 10^{3} \mathrm{~mL}^{-1}\right)$ & $28.33 \pm 26.43^{\mathrm{a}}(30)$ & $28.17 \pm 20.94^{\mathrm{a}}(26)$ & $29.14 \pm 24.43^{\mathrm{a}}(68)$ & $28.74 \pm 24.07(124)$ \\
Neutrophils $\left(\times 10^{3} \mathrm{ML}^{-1}\right)$ & $10.28 \pm 5.71^{\mathrm{a}}(17)$ & $7.91 \pm 6.71^{\mathrm{a}}(18)$ & $11.58 \pm 8.44^{\mathrm{a}}(43)$ & $10.45 \pm 7.60(78)$ \\
Lymphocytes $\left(\times 10^{3} \mathrm{HL}^{-1}\right)$ & $6 . .79 \pm 8 . .84^{\mathrm{a}}(17)$ & $10 . .78 \pm 10 . .0^{\mathrm{ab}}(18)$ & $12.52 \pm 12.00^{\mathrm{b}}(43)$ & $12.06 \pm 11.63(67)$ \\
Thrombocytes $\left(\times 10^{3} \mathrm{~mL}^{-1}\right)$ & $44.86 \pm 40.75^{\mathrm{a}}(14)$ & $39.53 \pm 20.70^{\mathrm{a}}(14)$ & $40.23 \pm 31.02^{\mathrm{a}}(44)$ & $41.00 \pm 31.13(44)$ \\
\hline
\end{tabular}

(1) number size; a, b, c $\mathrm{p}<0.05$. HTC: hematocrit, MCV: mean corpuscular volume, $\mathrm{MCH}$ : mean corpuscular hemoglobin, $\mathrm{MCHC}$ : mean corpuscular hemoglobin concentration, TPP: total plasmatic protein.

Erythrogram, leukogram, thrombocytogram, hematocrit measurement, were carried in the collected blood, hemoglobin dosage and total plasma protein dosage were also performed. The erythrocyte and leukocyte count were conducted using a Neubauer chamber, in which the erythrocyte was expressed in cells $\times 10^{6} \mathrm{~mL}^{-1}$ and the leukocyte in unit $\mathrm{mL}^{-1}$ and in percentage. For leukocyte, the differential count was determined using a blood extension in microscope slide. The hematocrit was determined by the microhematocrit method and expressed in percentage. Total plasma protein was obtained by refractometer. Using the hemoglobin dosage, expressed in $\mathrm{g} \mathrm{dL}^{-1}$, the number of erythrocyte and the hematocrit, the mean corpuscular volume (MCV) was calculated and expressed in $\mathrm{fL}$; the mean

\section{Discussion}

There was no significant difference between the hematological variables when compared by gender, in a study with Mugil platanus in 1995, in Cananéia SP, Brazil (RANZANI-PAIVA, 1995). Mugilidae with parasites, also in Cananéia SP, in 2002, when assessed by erythrogam did not show difference in the erythrocyte number between males, females and indefinite gender, although the male hematocrit was higher than the female and indefinite gender fish $(p<0.05)$ (Ranzani-Paiva e TavaresDias, 2002). In this study there was no significant difference $(P<0.05)$ in the erythrocyte count between the fish gender. Contrarily to that found in 2002 in Cananéia, in the present study 
there was difference, in the hematocrit, between male fish and the indefinite gender fish. However, it should be noted that the species are different in both studies, although the belong to the same family. Also, it is important to mention that the geographic and time are different.

Piaractus mesopotamicus hematology, from intensive culture, presented different values than those mentioned by the literature, differences attributed to factors such as seasonality, reproduction, diet habits, metabolic needs of each species, besides the ecophysiological conditions. Such individual variations may be considered expected, because the biological parameter in fish do not present a normal distribution (Tavares-Dias e Mataqueiro, 2004). However, this pattern is not stablished, as it already is for mammals, in this regard, this study is a collaboration to the establishment of a hematological parameters for $M$. curema. More studies regarding the growth and reproduction of this juvenile fish and in natural and controlled environment are needed.

The time scale influence was observed in the hematological parameters values of $M$. curema, in a study carried out in the estuary waters of Santos and Juréia, both localized at the coast of São Paulo state, Brazil. The mentioned relative difference was attributed to the distance between both estuaries and its different water qualities, considering that in Santos the water is more polluted. In this study, $7.52 \pm 2.24$ and $9.62 \pm 2.75 \times 10^{6}$ $\mathrm{mL}^{-1}$ of erythrocytes were registered in the summer and winter, respectively, in Santos, SP and 2.26 \pm 1.05 and $2.58 \pm 8.27 \times 10^{6}$ $\mathrm{mL}^{-1}$ in the summer and winter, respectively, in Juréia, SP (Cicero, 2015). The difference between the erythrocyte values in the Parati river study supports the conclusions mentioned above and may be awarded to the time conditions, in other words, the time scale influence. Although the time may be considered short

\section{References}

ALBIERI, R.J.; ARAÚJO, F.G.; UEARA, W. Differences in reproductive strategiesbetween two co-occurring mullets Mugil curema Valenciennes 1836 and Mugil liza Valenciennes 1836 (Mugilidae) in a tropical bay. Tropical Zoology, v.23, n.1, p.51-62, 2010.

ANDRADE, D.F.; OGLIARI, P.J. Estatística para ciências agrárias e biológicas: com noções de experimentação. 3 ed. rev. amp. Florianópolis: Ed. Da UFSC, 2013, 478p.

CICERO L.H. Avaliação das alterações da série vermelha do sangue de Mugil curema (Mugiliformes: Mugilidae) em distintas condições ambientais. 2015. 43p. Dissertação (Mestrado em Sustentabilidade de Ecossistemas Costeiros e Marinhos (ECOMAR), Universidade Santa Cecília, Santos, SP, 2015.

FONSÊCA F.T.B.; PARANAGUÁ, M.N.; AMADO M.A.M. Copepoda parasitas de peixes Mugilidae em cultivo estuarino Itamaracá - Pernambuco - Brasil. Trabalhos Oceanográficos da Universidade Federal de Pernambuco, v.28, n.2, p.157-172, 2000.

GHIRALDELLI, L.; MARTINS, M.L.; YAMASHITA, M.M.; JERÔNIMO, G.T. Hematologia de Oreochromis niloticus (Cichlidae) e Cyprinus carpio (Cyprinidae) mantidos em diferentes condições de manejo e alimentação no Estado de Santa

Catarina, Brasil. Acta Scientiarum. Biological Sciences, v.28, n.4, p.319-325, 2006. between both studies, the geographic conditions, weather, kind of estuary, anthropogenic action and others, are completely different and possible each of these conditions acts in a different way in the fish physiology.

The mugilid M. curema and Mugil incilis captures in Fortaleza, Ceará state, Brazil did not show strong differences between the species, albeit the sampling may be considered small, 12 $M$. curema and nine $M$. incilis. For erythrocyte they have found the average of 3.50 thousand cells by $\mathrm{mm}^{3}$, with a 2.60 to 4.40 thousand cells by $\mathrm{mm}^{3}$ range (Pitombeira et al., 1969). The number of erythrocytes by $\mathrm{mm}^{3}$ in the Parati river study was relatively close to the one found in Fortaleza. However, the range differed considerably, in which the variation in the cell numbers by $\mathrm{mm}^{3}$ in the fish studied in Parati river was relatively high, mostly if compared to the Fortaleza, CE, Northeast Brazil study. Once more, the time scale and the fish species, $M$. incilis, may substantiate those differences between both studies. Supporting such hypothesis, it was noted that the mugilid hematological characteristics, M. platanus, grown in different environments, fresh water and estuary did differ in hematological characteristics (Ranzani-Paiva e Ishikawa, 1996).

\section{Conclusion}

The local population of the studied fish has a proper behavior in hematological descriptors, which is different from other Brazilian coast studies with the same fish species. Hematological results of $M$. curema, from the Parati river, Araquari, SC, Brazil, highlight the importance of future studies to report the effects of the estuary and the anthropic action around the Parati river, besides the behavior and physiology of the studied species and compare it to close regions.

HAMMER Ø.; HARPER D.A.T.; RYAN P.D. PAST: Paleontological statistics software package for education and data analysis. Palaeontologia Electronica. v.4, n.1, p.1-9, 2001.

MENEZES N.A. Guia prático para conhecimento e identificação de tainhas e paratis (Pisces, Mugilidae) do litoral brasileiro. Revista Brasileira de Zoologia, v.2, n.1, p.1-12, 1983.

MENEZES N.A.; NIRCHIO M.; OLIVEIRA C.; SICCHARAMIREZ R. Taxonomic review of the species of Mugil (Teleostei: Perciformes: Mugilidae) from the Atlantic South Caribbean and South America, with integration of morphological, cytogenetic and molecular data. Zootaxa, v.3918, n.1, p. 001-038, 2015.

PETRIE, A.; WATSON P. Estatística em ciência animal e veterinária. São Paulo: Roca, 2009, 236p.

PITOMBEIRA, M.S.; GOMES, F.V.B.; MARTINS J.M. Hematological data on the fishes of the genus Mugil Linnaeus. Arquivos de Ciência do Mar, v.9, n.2, p.163-166, 1969.

R CORE TEAM. $R$ : A language and environment for statistical computing. R Foundation for Statistical Computing, Vienna, Austria, 2017. https://www.R-project.org/.

RANZANI-PAIVA M.J.T. Características hematológicas de tainha Mugil platanus Günther, 1880 (Osteichthyes, Mugilidae) da região estuarino-lagunar de Cananéia - SP (Lat. 2500' - Long 47055”W). Boletim do Instituto de Pesca, v.22, n.1, p.1-22, 1995. 
RANZANI-PAIVA M.J.T.; ISHIKAWA C.M. Haematological characteristics of freshwater-reareo ano wilo mullet, Mugil platanus Günther (Osteichthyes, Mugilidae). Revista Brasileira de Zoologia, v.19, n.3, p.807-818, 1996.

RANZANI-PAIVA M.J.T.; TAVARES-DIAS, M. Eritrograma, relação viscerosomática, hepatosomática e esplenosomática em tainhas Mugil platanus Günther (Osteichthyes, Mugilidae) parasitadas. Revista Brasileira de Zoologia, v.19, n.3, p.807-818, 2002.

RANZANI-PAIVA, M.J.T.; PÁDUA, S.B.; TAVARES-DIAS, M.; EGAMI, M.I. Métodos para análise hematológica em peixes. Maringá: Eduem, 2013, 140p.
SILVA, A.S.E.; LIMA, J.T.A.X.; BLANCO, S.B. Hematologia em peixes. Revista Centauro, v.3, n.1, p.24-32, 2012.

TAVARES-DIAS M.; MATAQUEIRO, M.I. Características hematológicas, bioquímicas e biométricas de Piaractus mesopotamicus Holmberg, 1887 (Osteichthyes: Characidae) oriundos de cultivo intensivo. Acta Scientiarum. Biological Sciences, v.26, n.2, p.157-162, 2004. 